\title{
Polyphasic origin of salinity in the Senegal delta and middle valley
}

\author{
Laurent Barbiéro ${ }^{\mathrm{a}, \mathrm{b}, *}$, Abdallahi Ould Mohamedou, \\ Caroline Laperrousaz ${ }^{\mathrm{d}}$, Sônia Furian ${ }^{\mathrm{e}}$, Sébastien Cunnac ${ }^{\mathrm{f}}$ \\ ${ }^{a}$ Indo-French Cell for Water Sciences, Department of Civil Engineering, \\ Indian Institute of Science, 560012 Bangalore, India \\ ' IRD-UR 154, Laboratoire des Mécanismes de Transfert en Géologie, \\ 14, avenue Edouard Belin, 31400 Toulouse, France \\ ${ }^{\mathrm{c}}$ FST, B.P. 5026, Nouakchott, Mauritania \\ ${ }^{\mathrm{d}}$ Unité de Sciences du Sol et Agronomie, ENSA, 65 rue de St Brieuc, 35000 Rennes, France \\ ${ }^{\mathrm{e}}$ Departamento de Geografia, USP-FFLCH, CP 8105, Cep 05508-900, São Paulo SP, Brazil \\ ${ }^{\mathrm{f}}$ ESA Purpan, 75, rue du TOEC, 31076, Toulouse Cedex 3, France
}

\begin{abstract}
Saline areas are a major obstacle to the development of sustainable irrigated agriculture in the Senegal valley. They have been attributed to the incorporation of marine salts in the sediments during the last marine transgression. However, this does not explain their geomorphological situation and geochemical features. They are distributed as strips about 100-200 m wide and several kilometers long, which are composed of two parallel substrips, one located in the depressions of former creek beds, and the other on higher ground on the southern bank. In these two substrips, the chemical composition of salinity and its distribution in the soil suggest that it arises from more than one source. Comparison of saline areas of the middle valley with present-day salt accumulation in the delta suggests a four-stage salinization process, which involves evaporation from a shallow water table, aeolian salt accumulation as clay dunes, deep transformation of shell beds into gypseous layers under temporary acid conditions induced by oxidation of pyrite under the mangrove vegetation, and secondary salinization by runoff. The four-stage model agrees with a regional salinity chemical database and the geomorphology of the saline areas. In the Senegal valley, the lower middle valley and the delta can therefore be regarded as a chronosequence, the recent salinity features occurring in the delta and the more developed ones upriver at the limit of the marine transgression.
\end{abstract}

Keywords: Salinity; Soil genesis; Aeolian deflation; Clay dune; Upscaling; Senegal valley

\footnotetext{
* Corresponding author.

E-mail address: barbiero@civil.iisc.ernet.in (L. Barbiéro).
} 


\section{Introduction}

Salinization and alkalinization of soils and waters occur widely in arid and semi-arid regions (Szabolcs, 1992). In the West African Sahelian zone, these problems affect all irrigation schemes, because of poor management of irrigation (Bertrand et al., 1997). In the Senegal river valley, located in North Senegal and South Mauritania, development of irrigated agriculture is one of the main purposes of the Manantali and Diama Dams (Organisation pour la Mise en Valeur du fleuve Sénégal (OMVS, 1975)). However, the extensive saline soils, which existed prior to establishment of the irrigation schemes, are a major threat to this development. The problem is encountered especially in the delta and lower middle valley (Loyer, 1989; Boivin, 1997).

In this region, soil salinity has been attributed to a present (in the delta) or former (in the middle valley) shallow, saline water table, resulting from a succession of recent transgressions and regressions of the Atlantic Ocean during the late Holocene (last 6000 years) (Michel, 1973; Le Brusq, 1980; Loyer, 1989; Ceuppens and Wopereis, 1999). Michel (1973) and Deckers et al. (1997) stated that the last transgression, which started about 2000 years ago (Faure et al., 1980), was responsible for incorporation of marine salt into the sediments in which the soils have formed (Maymard and Combeau, 1960). However, preliminary studies in the middle valley showed that saline areas form roughly E-W strips $>10 \mathrm{~km}$ long and 100-200 m wide (Barbiéro et al., 2001). This distribution of salt does not agree with a simple scenario of salt incorporation in the sediment during the latest transgression.

In this paper, we propose a model explaining the distribution of salt, taking into account the geomorphological and geochemical features of the saline areas in the Senegal middle valley and delta, and also a regional database of salinity chemistry.

\section{Site details}

In the Senegal valley, the soils have developed from alluvial deposits following the last marine regression that occurred 2000 years ago (Faure et al., 1980). They form a chronosequence in which the recent soils occur in the delta and older ones, which are more strongly developed, occur upriver in the middle valley at the limit of the last marine transgression. The several processes formerly responsible for soil features in the middle valley are still active downstream in the lower middle valley or in the delta (Barbiéro et al., in press). We therefore compared salinity characteristics at two sites in the Senegal valley, one along the N'Galenka creek in the Podor region of the middle valley (northern Senegal) and the other in the Diawling National Park in the Senegal delta (southern Mauritania) (Fig. 1).

The semiarid climate of the area is characterised by a wet season (approximately 200 $\mathrm{mm}$ of rainfall) from July to September, a cold and dry season from October to February and a hot dry season from March to June. The temperature averages $23{ }^{\circ} \mathrm{C}$ in January and $33{ }^{\circ} \mathrm{C}$ in May, with daily maximum over $41{ }^{\circ} \mathrm{C}$. The prevailing winds blow from the NE (Harmattan) in the middle valley and from NE to NW in the delta because of the coastal influence. The dry and warm winds increase evaporative demand and create a plant-water 


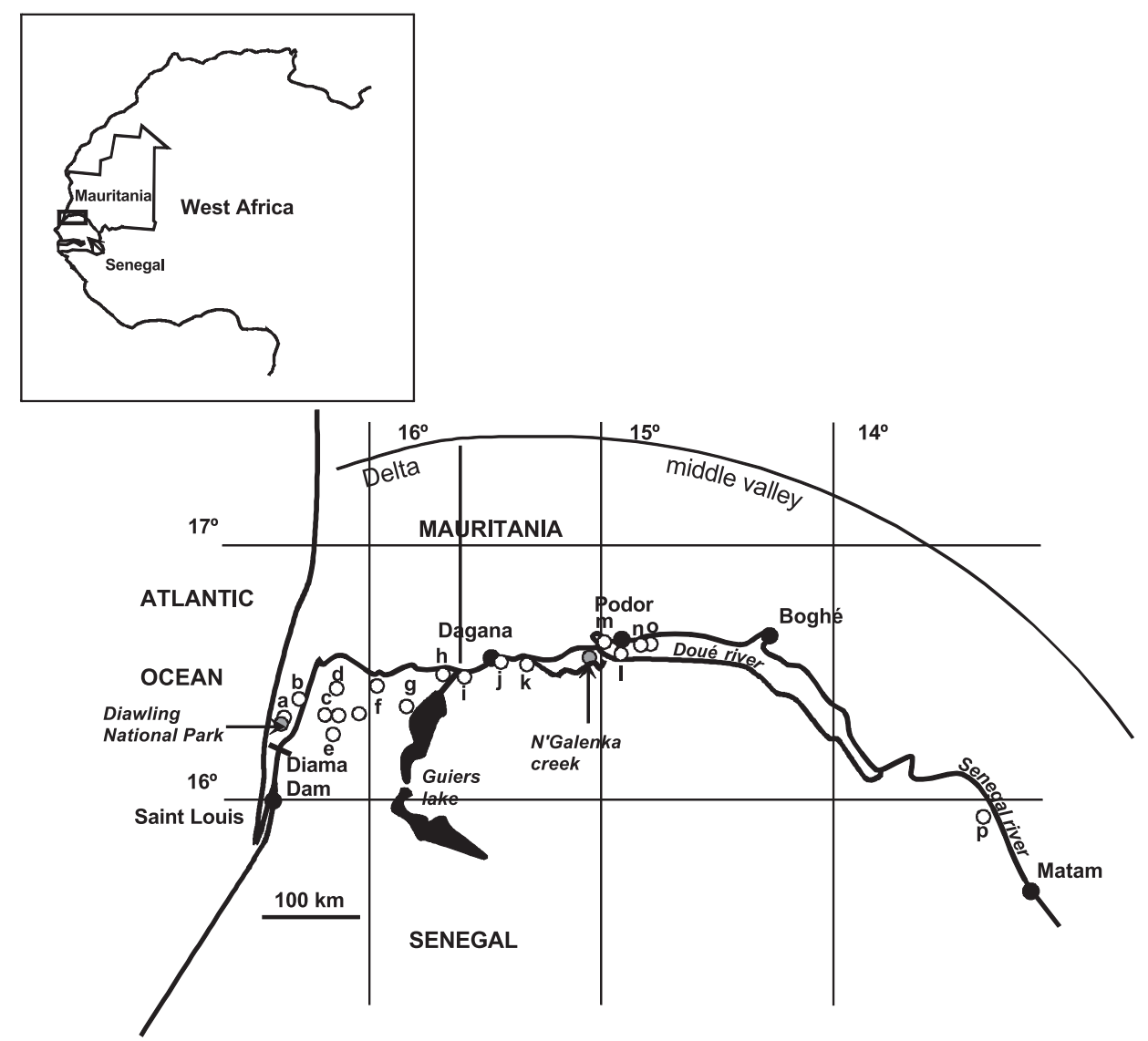

Fig. 1. Location of the studied sites in the Senegal valley. $a-p$ are sites where the geochemical database was collected. (a) Khurumbam; (b) Keur Macene; (c) N'Diaye; (d) Gorom; (e) Lampsar; (f) Boundoum; (g) N'Der; (h) Rosso; (i) Balky; (j) Dagana; (k) Fanaye; (1) Nianga; (m) N'Gaoule; (n) Donaye; (o) M'Boyo; (p) Kobilo.

imbalance. Average Class A pan evaporation exceeds average rainfall for each month and by an annual total of $2800 \mathrm{~mm}$ (Verheye, 1995).

\subsection{The middle valley}

The N'Galenka creek, in the Podor region, extends from $16^{\circ} 26^{\prime} \mathrm{N}$ to $16^{\circ} 30^{\prime} \mathrm{N}$ and from $14^{\circ} 50^{\prime} \mathrm{W}$ to $15^{\circ} 05^{\prime} \mathrm{W}$. Two major geomorphological units are distinguished: depressions and former river-banks (FAO-SEDAGRI, 1973), which are occupied respectively by Vertisols and Fluvisols (FAO/ISRIC/ISSS, 1998). They are known locally as Hollaldé and Fondé soils (Maymard and Combeau, 1960). Fondé soils contains about 30\% clay, and their saturated hydraulic conductivity ranges from $10^{-6}$ to $10^{-5} \mathrm{~m} \mathrm{~s}^{-1}$ (Meyer, 1997). Hollaldé soils contain about $60 \%$ clay, which is composed of smectite $(30-40 \%)$, kaolinite (35-40\%), interstratified illite-smectite (15-20\%), and mica (5-10\%) (Moha- 


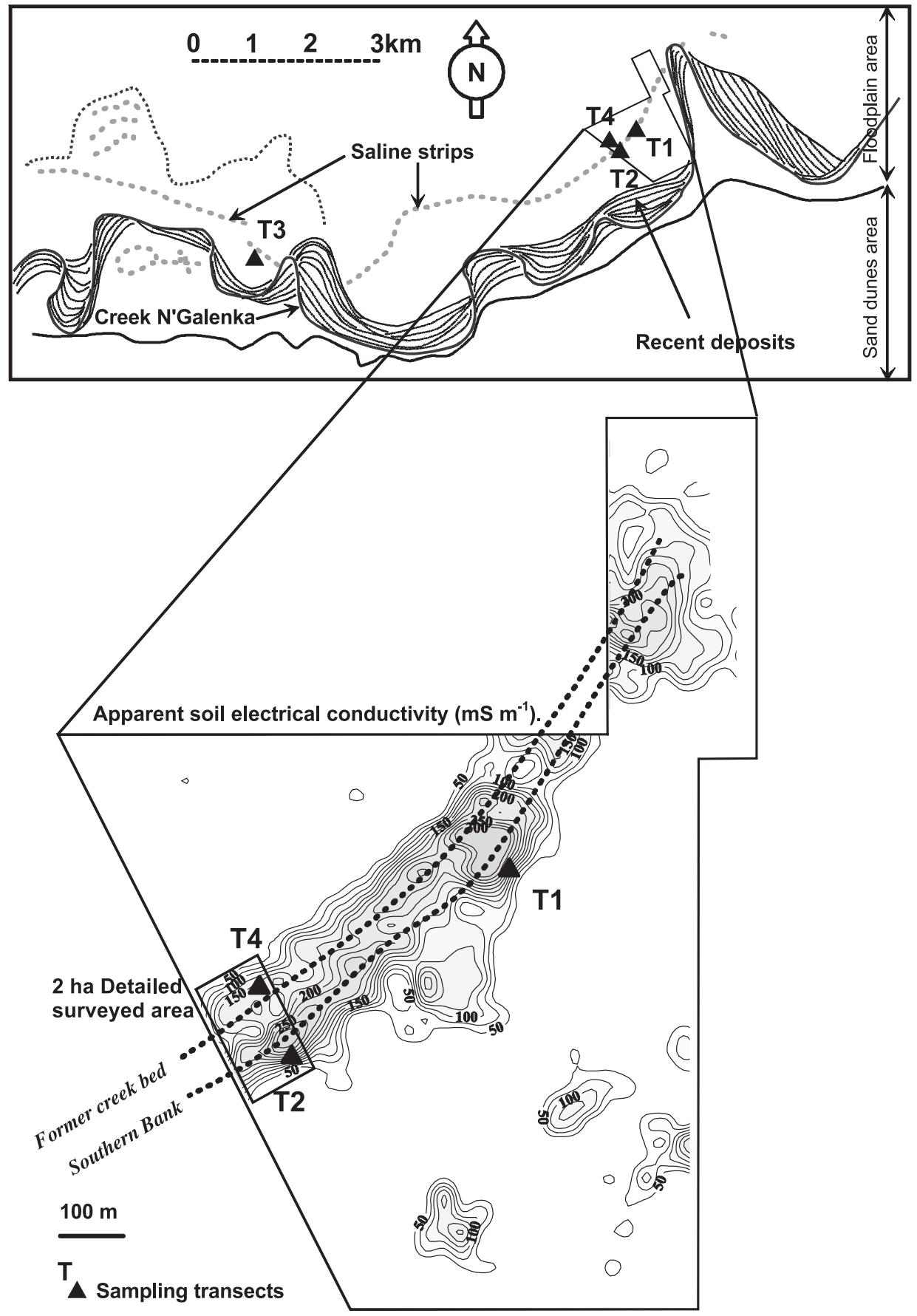

Fig. 2. Area studied and transects sampled in the N'Galenka area (modified from Barbiéro et al., 2001). 
medou, 2000; Barbiéro et al., in press). Their saturated hydraulic conductivity is around $10^{-7} \mathrm{~m} \mathrm{~s}^{-1}$. The Hollaldé soils constitute the best areas for irrigated rice growing because of their suitable physical and chemical properties. The water table occurs generally at about $7 \mathrm{~m}$ depth and the electrical conductivity (EC) of the groundwater ranges from 0.15 to $1 \mathrm{dS} \mathrm{m}^{-1}$ (Zanolin et al., 1997; Hammecker and Maeght, 2002).

Surveys of soil salinity in the Podor region have been done at the paddy field scale (15 ha) (De Poitevin, 1993; Diba, 1995; Laval, 1996) or over a larger area (288 ha) with a low density of measurements directed towards a geostatistical study of soil sampling (Gascuel-Odoux and Boivin, 1994). None of these had the objective of understanding the shape and distribution of saline areas in the landscape. More recently, an exhaustive survey of salinity covered a large area of 8000 ha at N'Galenka (Fig. 2), revealing 14 saline areas, distributed as strips that are several kilometers long and 100-200 m wide (Cunnac, 1996; Barbiéro and Laperrousaz, 1999, Barbiéro et al., 2001). The strips are related to former creek channels and do not correspond to present-day salt remobilisation. A detailed study of one strip (Fig. 3) showed that it consists of two parallel substrips, a northern substrip lying in the depression of a former creek bed and a southern substrip on slightly higher ground on the southern bank of the creek (Barbiéro et al., 2001).

(a)

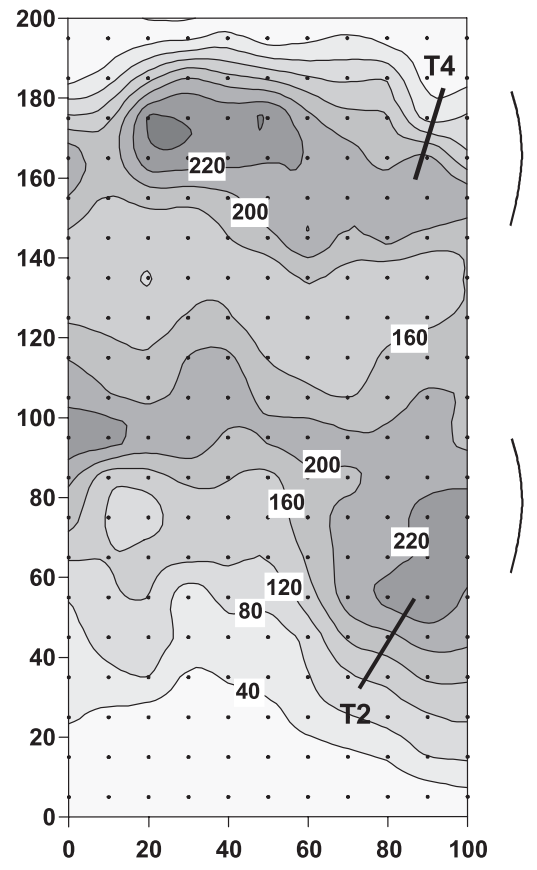

Apparent soil electrical conductivity $\left(\mathrm{mS} \mathrm{m}^{-1}\right)$. (b)

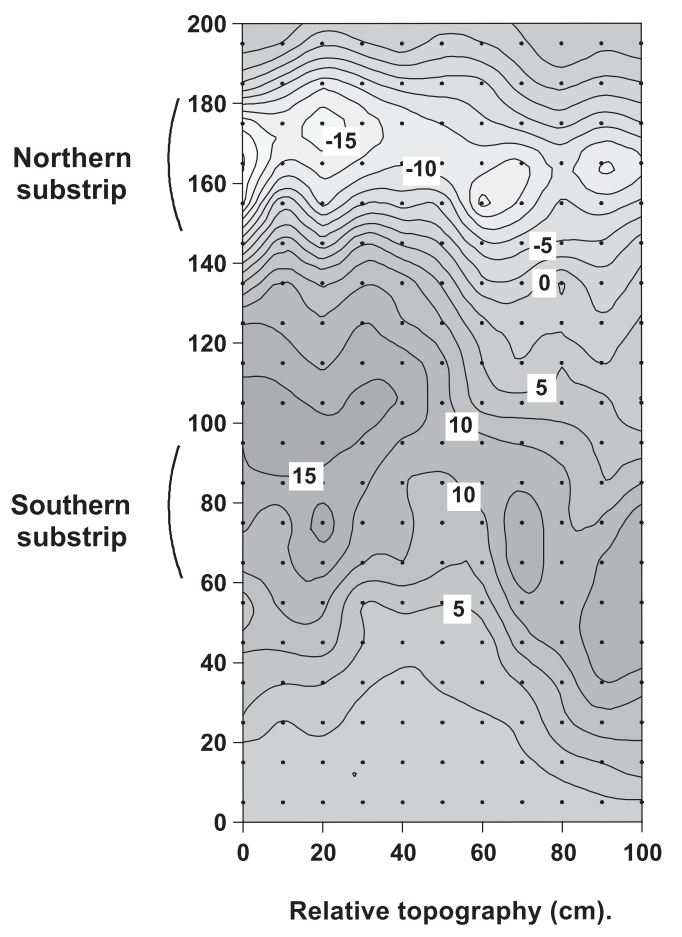

Fig. 3. Topography (a) and distribution of electromagnetic conductivity (b) in a saline strip showing that the northern substrip is located in a depression and the southern substrip on higher ground (modified from Barbiéro et al., 2001). (.) Denotes measurement points. 


\subsection{The delta}

In the delta, fieldwork was concentrated between the Birette and Ziré dunes close to the creek Khurumbam, in the Bell basin (Fig. 4). The main soil types here are Gypsic Fluvisols, Calcic Gypsic Fluvisols and Vertisols (FAO/ISRIC/ISSS, 1998), though Thionic Fluvisols containing pyrite $\left(\mathrm{FeS}_{2}\right)$ and jarosite $\left[\mathrm{KFe}_{3}\left(\mathrm{SO}_{4}\right)_{2}(\mathrm{OH})_{6}\right]$ also occur near the remaining mangroves (Le Brusq et al., 1987; Deckers et al., 1997). Although this site is today protected from tidal influence by a large embankment, it is partially flooded from July to September during the wet season. The water table is at $0.1-1.2 \mathrm{~m}$ depth and the electrical conductivity ranges from 8 to $130 \mathrm{dS} \mathrm{m}^{-1}$. Because of salinity, clay dunes are a distinctive feature of this area. From November to June, the salinity of the water and soil increases because of intense evaporation. When the topsoil dries, the increasing salinity and rapid crystallization of salts such as gypsum and halite cause the mud to flocculate forming silt and sand size aggregates, which are vulnerable to wind erosion. These aggregates accumulate on leeward sides of all wind-breaking obstacles to form saline clay dunes (Mohamedou et al., 1999). The environmental conditions favouring formation of clay dunes are very specific. They require a prevailing wind during the dry season, temporary saline pan conditions, and a specific clay content in the topsoil (Price, 1963; Vieillefon, 1967; Bowler, 1973; Thomas, 1988; Thomas et al., 1993; Barbiéro et al., 1998a).

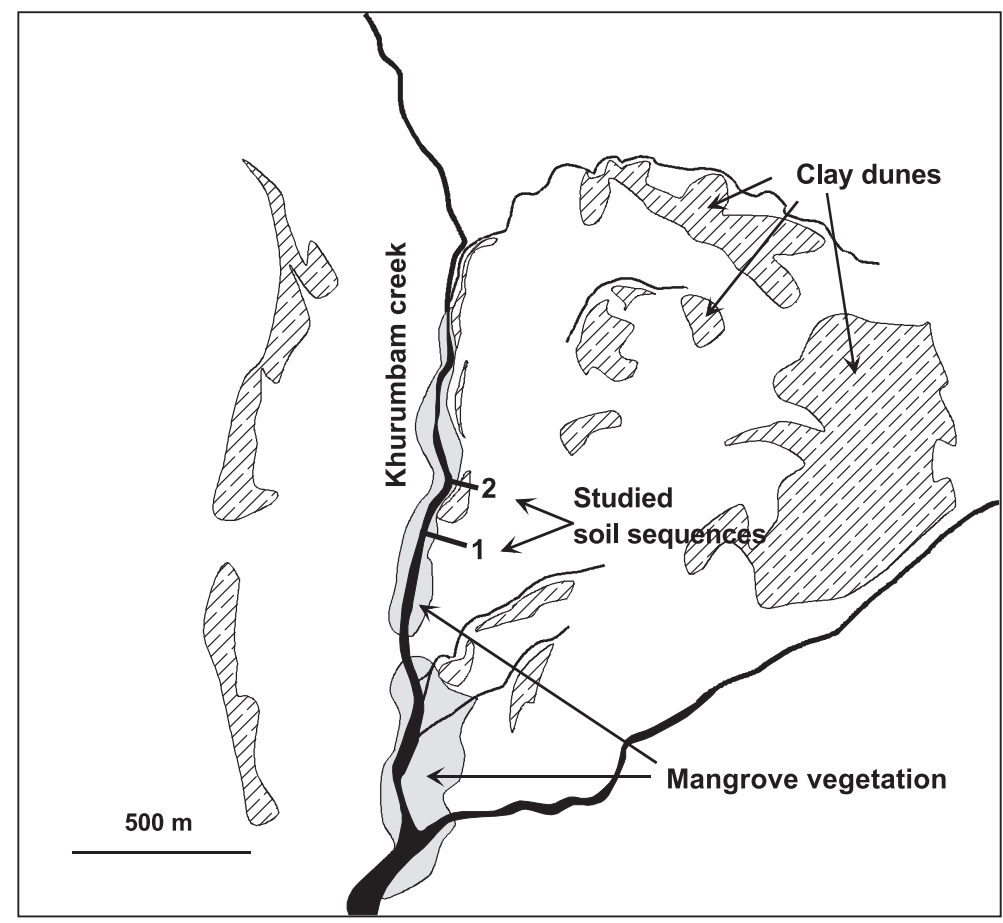

Fig. 4. Location of the soil toposequences studied along the Khurumbam creek in the Bell basin. 


\section{Materials and methods}

\subsection{Middle valley}

Around Podor, six sites were selected from aerial photographs (Geotronics, 1980) in order to verify the distribution pattern of salinity. A survey of salinity was attempted by soil electromagnetic induction transects (EM38, Geonics) (McNeill, 1992) intersecting the structures suspected to be saline on the photographs. Electromagnetic conductivity $(\mathrm{ECm})$ values $>150 \mathrm{mS} \mathrm{m}^{-1}$ were noted and saline areas were hand drawn over the background of aerial photographs. A 20-km-long saline strip, composed of two parallel substrips and crossing the whole N'Galenka region was selected for a detailed study. Four short transects across the strip (T1-T4, Fig. 2) were located using electromagnetic induction measurements to maximize the range of salinity sampled (Fig. 3). They were respectively 34, 27 , 35 and $24 \mathrm{~m}$ long. T1, T2 and T3 cross the southern substrip of the saline area, whereas T4 crosses the northern one and is partly in the former creek bed. Soil samples along these transects were taken with a hand auger in a total of 35 profiles ( 8 on T1, 10 on T2 and T3, 7 on T4), each at four depths $(0-0.2,0.3-0.5,0.7-0.9$ and $1.1-1.3 \mathrm{~m})$.

The electrical conductivity was measured on solutions extracted by centrifuging 1:5 soil-water mixtures using distilled-deionized water. Magnesium, sodium, calcium and potassium concentrations in the extracts were measured by atomic absorption spectrometry (Perkin Elmer). Chloride and sulfate ion concentrations were determined by capillary electrophoresis (Waters Capillary Ion Analyser). The carbonate alkalinity was measured by $\mathrm{HCl}$ titration (Gran, 1952).

\subsection{The delta}

Two soil sequences were studied in the delta, across the Khurumbam creek bed and across the clay dunes fringing the creek. They were respectively 100 and $40 \mathrm{~m}$ long (Fig. 4). The horizons are described according to the classification for Acid Sulfate Soils of the International Institute for Land Reclamation and Improvement (Dent, 1986). Topography was determined using a Topochaix ${ }^{\circledR}$ theodolite. In the first sequence, the soil morphology was reconstructed from 11 holes bored with a hand auger and 3 pits excavated on the main lateral transitions of soil horizons. In the second sequence, it was studied from 15 holes and 1 pit located at the top of the clay dune. Seventy-six soil samples were taken in the second sequence reaching from in and beneath the clay dune to the creek. Saturated extracts from these samples were analysed by the methods described in Section 3.1. The chemical results from the second sequence were presented by Mohamedou et al. (1999). Salt efflorescences were collected for SEM (XL20 Philips) observations and chemical analysis (LINK Analytical eXL energy dispersive X-ray system).

\subsection{Regional database}

To estimate how representative our samples from the middle valley and delta were for developing a regional model of soil salinization, they were compared to a regional database of 1784 samples of 1:5 soil-water extracts. The data were from various locations 
( $\mathrm{a}-\mathrm{p}$ on Fig. 1), most of them obtained before establishment of the irrigated rice growing schemes (Maymard, 1952; Braudeau, 1978, 1981; Loyer and Diallo, 1979; Loyer and M'Timet, 1979; Le Brusq, 1980; Brito, 1982; Mougenot, 1982; Seiny Boukar, 1983; Loyer, 1989; Laval, 1996; Samba Diene, 1998; Mohamedou, 1998; Barbiéro et al., 1998b; Mohamedou et al., 2001a). Most of the analyses for this database were made at IRD laboratory (Institut de Recherche pour le Développement, previously ORSTOM) in Dakar.

\section{Results}

\subsection{Salinity in the middle valley}

The relationship between saline strips and geomorphological features at several sites in the Podor region is presented in Fig. 5. The survey of soil salinity using the electromagnetic conductivity meter (EM38) reveals a unique pattern: The salt is distributed as strips along former creek beds. The saline strips are frequently divided into two parallel substrips with the northern saline substrip located in the former creek bed, and the southern fringing the creek bed on the southern bank (Fig. 5a, c, e and f).

The chemical composition of the soil extract is plotted in Piper diagrams (Fig. 6). The composition of the least saline samples is dominated by alkalinity and $\mathrm{Ca}^{2+}$. In the most saline samples, the anionic composition is dominated either by $\mathrm{Cl}^{-}$or $\mathrm{SO}_{4}^{2-}$, and the cations by $\mathrm{Na}^{+}+\mathrm{K}^{+}$. Further discussion here is based on the distribution of $\mathrm{Cl}^{-}$and $\mathrm{SO}_{4}^{2-}$. Table 1 compares summary statistics for $\mathrm{EC}, \mathrm{Cl}^{-}$and $\mathrm{SO}_{4}^{2-}$ concentrations in the soil extracts from transects at N'Galenka with the regional database. All three at N'Galenka are within the ranges for the regional database. However, the chemistry differs because average $\mathrm{SO}_{4}^{2-}$ is greater than average $\mathrm{Cl}^{-}$in all four transects, but less than average $\mathrm{Cl}^{-}$in the regional database.

The concentrations of $\mathrm{Cl}^{-}$and $\mathrm{SO}_{4}^{2-}$ in samples from the middle valley suggest two groups of samples (Fig. 7). Group 1 is relatively scattered and the $\mathrm{SO}_{4}^{2-}$ concentration increases in proportion to $\mathrm{Cl}^{-}$. This group includes mainly superficial $(0-0.2 \mathrm{~m})$ samples and deep samples collected in the former creek bed on T4. Group 2 includes mainly deeper samples $(0.3-1.3 \mathrm{~m})$ dominated by $\mathrm{SO}_{4}^{2-}$. The $\mathrm{SO}_{4}^{2-}$ contents are fairly constant, irrespective of $\mathrm{Cl}^{-}$contents.

The distributions of $\mathrm{EC}, \mathrm{Cl}^{-}$and $\mathrm{SO}_{4}^{2-}$ along the soil transects at N'Galenka are presented in Fig. 8. The contours were hand drawn using inverse distance methods between neighbouring sampling points. Maximum EC occurs around $80 \mathrm{~cm}$ depth in all four transects. $\mathrm{SO}_{4}^{2-}$ follows roughly the same distribution, but $\mathrm{Cl}^{-}$increases upwards in all the transects except at the end of $\mathrm{T} 4$ in the former creek bed, where maximum $\mathrm{Cl}^{-}$ occurs at depth.

\subsection{Soil system and chemistry in the delta}

Fig. 9 shows the typical soil distribution pattern in the delta. In the creek bed at the extreme western end of sequence 1, unripe silty clay material with a high pyrite content occurs at $0.4 \mathrm{~m}$ depth, and is overlain by a greyish brown, silty clay, half ripe material, 

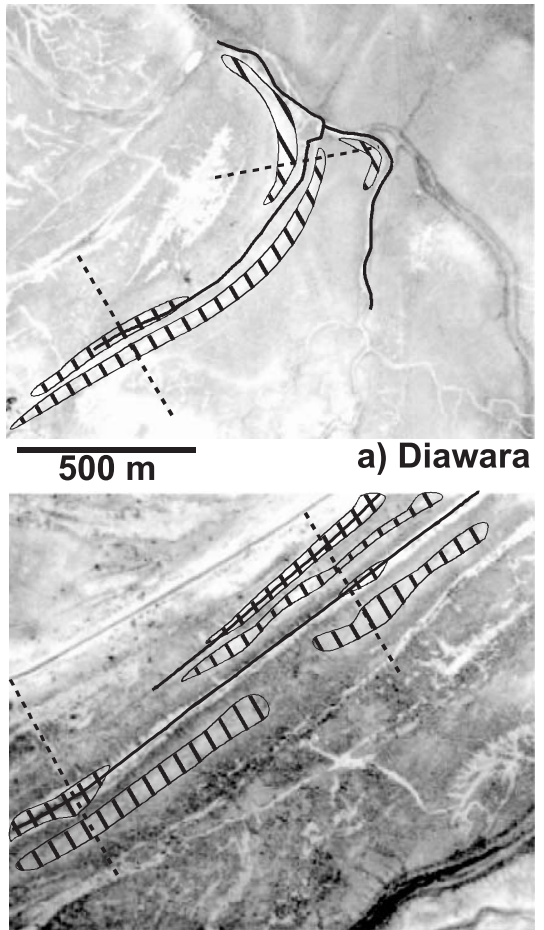

c) N'Diayene Walo

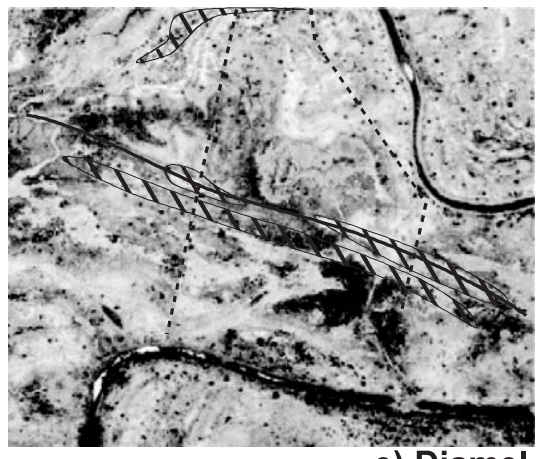

e) Diamel

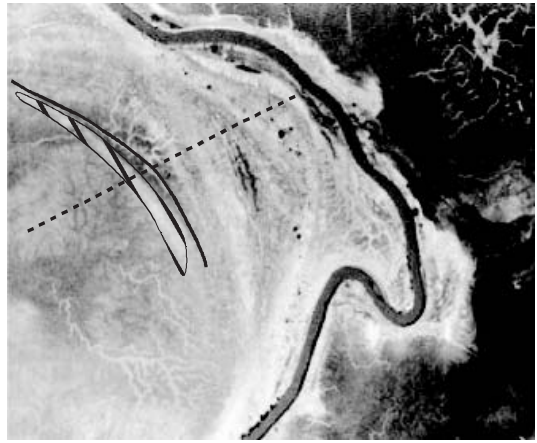

b) Diawara

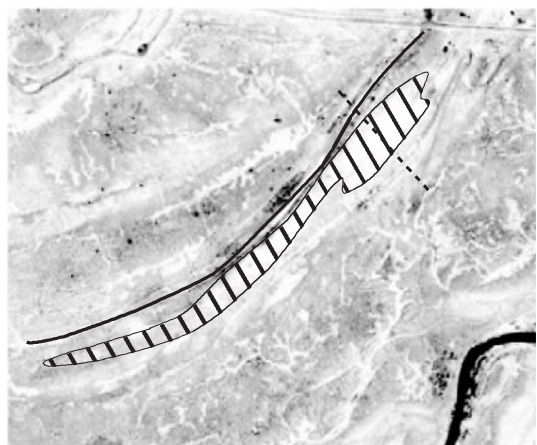

d) Nianga Walo

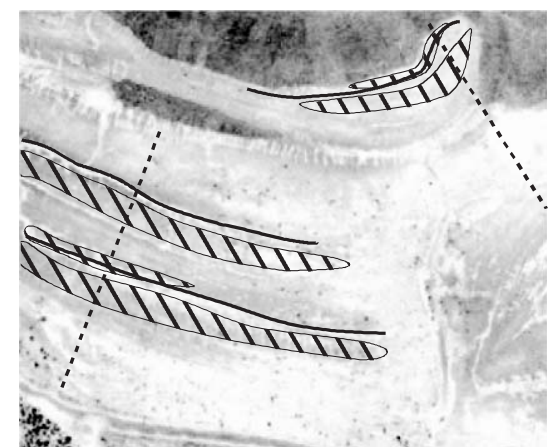

f) N'Diayene Walo

Former creek bed

Fig. 5. Aerial photographs showing strip pattern of saline areas and their relationship to former creek channels at six sites in the Podor region.

very acidic and with yellow mottles of jarosite. The greyish brown horizon has a coarse prismatic structure and some reddish brown (iron oxide) mottles at the base. The surface soil has a soft powdery structure. 
Mg

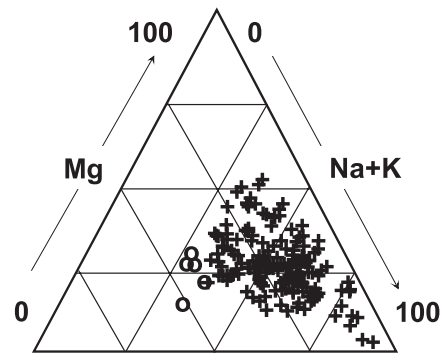

$\mathrm{Ca}$

100
$\mathrm{Ca}$
$\mathrm{Na}+\mathrm{K}$

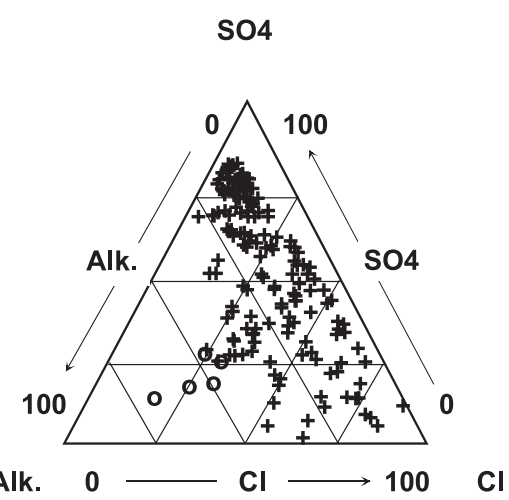

Fig. 6. Piper diagrams showing the variability in the chemical composition of the soil aqueous extracts along the transects studied in the N'Galenka area. Open circles denote the five least saline samples.

At $0.2 \mathrm{~m}$ depth, near $12 \mathrm{~m}$ to the east, a bleached sandy horizon begins. It is discontinuous between 12 and $24 \mathrm{~m}$ and its lower boundary, as seen in the pit at $24 \mathrm{~m}$ is abrupt, wavy and emphasized by reddish hematite mottles. The thickness of this horizon increases progressively from 0.2 to $0.95 \mathrm{~m}$ between 24 and $100 \mathrm{~m}$. It is locally bleached, but around the former mangrove roots, it is coloured by iron oxide. Near $66 \mathrm{~m}$, an abrupt change occurs in the surface structure from soft powder to centimetric platelets, which corresponds to an increase in topsoil clay content. The thickness of this clay topsoil horizon increases irregularly from $66 \mathrm{~m}$ to the end $(100 \mathrm{~m})$ of the surveyed transect, where a decimetric vertic structure appears and the clay content reaches 49\% (Mohamedou et al., 2001b).

Two layers rich in shells and shell fragments are found in the western part of sequence 1. The first layer at $0.6 \mathrm{~m}$ depth is composed of Anadara senelis fragments and the second $(0.9 \mathrm{~m}$ depth) of Thympanotonus fuscatus shells. In both layers, the shells are hard only up to 33 and $62 \mathrm{~m}$, respectively. Further east, they are replaced by shells weathered by dissolution, and yet further centimetric gypseous nodules replace the two shell layers.

Table 1

Comparison of the descriptive statistics of the $\mathrm{EC}\left(\mathrm{mS} \mathrm{cm}^{-1}\right), \mathrm{Cl}$ and $\mathrm{SO}_{4}$ contents $\left(\mathrm{meq}^{-1}\right)$ measured on the soil extracts in transects T1-T4 in the N'Galenka area with the regional database of 1784 samples

\begin{tabular}{|c|c|c|c|c|c|c|c|c|c|c|c|c|c|c|c|}
\hline & \multicolumn{3}{|l|}{$\mathrm{T} 1$} & \multicolumn{3}{|l|}{$\mathrm{T} 2$} & \multicolumn{3}{|l|}{$\mathrm{T} 3$} & \multicolumn{3}{|l|}{$\mathrm{T} 4$} & \multicolumn{3}{|c|}{ Regional database } \\
\hline & $\mathrm{Cl}$ & $\mathrm{SO}_{4}$ & $\mathrm{EC}$ & $\mathrm{Cl}$ & $\mathrm{SO}_{4}$ & $\mathrm{EC}$ & $\mathrm{Cl}$ & $\mathrm{SO}_{4}$ & $\mathrm{EC}$ & $\mathrm{Cl}$ & $\mathrm{SO}_{4}$ & $\mathrm{EC}$ & $\mathrm{Cl}$ & $\mathrm{SO}_{4}$ & $\mathrm{EC}$ \\
\hline $\begin{array}{c}\text { Number of } \\
\text { samples }\end{array}$ & 32 & 32 & 32 & 40 & 40 & 40 & 40 & 40 & 40 & 28 & 28 & 28 & 1784 & 1784 & 1784 \\
\hline Mean value & 5.72 & 22.26 & 2.71 & 11.43 & 16.6 & 3.43 & 6.17 & 32.06 & 4.18 & 2.13 & 31.87 & 3.26 & 12.42 & 6.07 & 5.66 \\
\hline $\begin{array}{l}\text { Standard } \\
\text { deviation }\end{array}$ & 4.36 & 28.26 & 2.42 & 5.99 & 13.77 & 1.58 & 3.90 & 14.46 & 0.96 & 1.89 & 24.46 & 2.06 & 1726.1 & 84.11 & 165.24 \\
\hline Minimum & 0.21 & 0.26 & 0.12 & 2 & 1.2 & 0.7 & 0.24 & 7 & 1.89 & 0.25 & 0.98 & 0.16 & 0.01 & 0.01 & 0.12 \\
\hline Maximum & 14 & 85 & 5.92 & 25 & 47 & 6.97 & 15 & 52 & 4.67 & 6.70 & 69 & 6.26 & 4280 & 187 & 412 \\
\hline
\end{tabular}




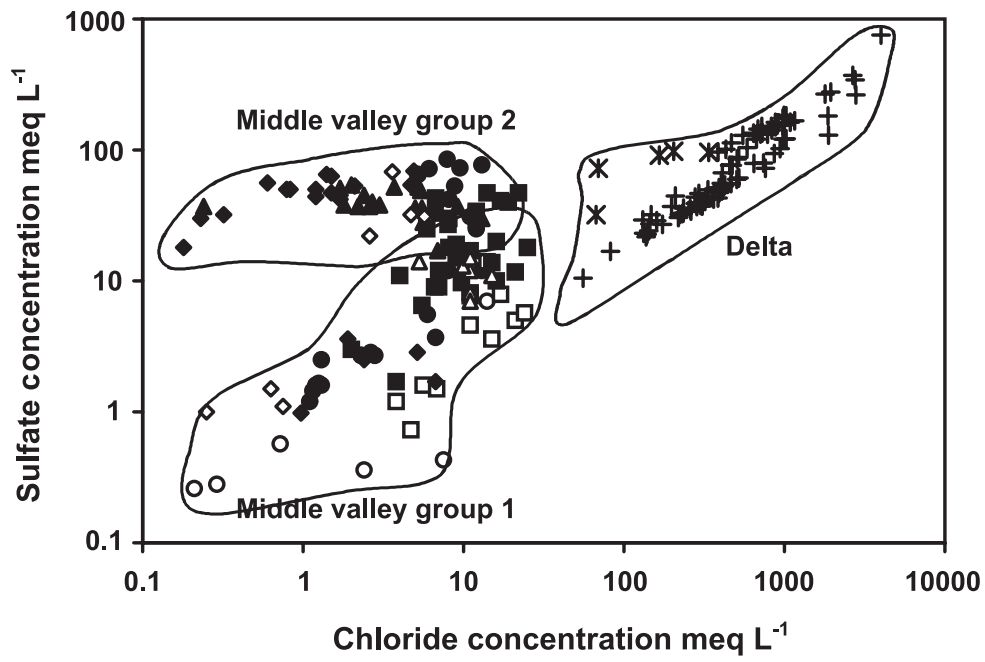

Fig. 7. Relationship between chloride and sulfate concentrations in N'Galenka area and Diawling Park. At N'Galenka (middle valley): $(\bigcirc) \mathrm{T} 1 ;(\square) \mathrm{T} 2 ;(\triangle) \mathrm{T} 3 ;(\diamond) \mathrm{T}$, open symbols are superficial samples $(0-0.2 \mathrm{~m})$, closed symbols are deeper samples $(0.3-1.3 \mathrm{~m})$; + and asterisks: toposequence 2 from Diawling park in the delta. Asterisks are samples taken from the gypseous layer beneath the clay dune.

Aeolian accumulation of aggregates blown from the surrounding soils forms elongated clay dunes. Because the prevailing winds are from the north and northwest, the dunes are behind the remains of mangrove vegetation along the southern and southeastern bank of the Khurumbam creek and its tributaries. They are about $1 \mathrm{~m}$ high, 30-40 $\mathrm{m}$ wide and 0.3-4 km long (Mohamedou et al., 2001b).

The soil system described in sequence 1 also occurs beneath the clay dune of sequence 2 (Fig. 9). The bleached sandy horizon is well developed but discontinuous. Two shell layers partially dissolved occur in the western part of the sequence, close to the Khurumbam. The clay dune itself is composed of stratified sandy clay loam composed of layers about $1 \mathrm{~mm}$ thick; four of them, more sandy, were identified in the pit and auger holes. Some former leaves of mangrove vegetation were observed at the base of the dune material. The floor of the clay dune is slightly undulating and higher than the surrounding land surface by about $0.4 \mathrm{~m}$.

Samples taken in the delta contained greater concentrations of soluble salt than those from the middle valley. A good correlation $\left(r^{2}=0.98\right.$, slope $\left.=0.94\right)$ occurs between $\mathrm{Cl}^{-}$and $\mathrm{SO}_{4}^{2-}$ (+ in Fig. 7). In Fig. 7, the scatter plot continues that of the group 1 samples from the middle valley. However, some points slightly departing from the correlation (asterisks in Fig. 7) are more in continuity with the scatter plot of group 2. These points are for samples taken beneath the clay dune in the shell bed and gypseous layers, and Mohamedou et al. (1999) have shown that the soil solution at such points is at equilibrium with respect to gypsum.

The saline efflorescences on the soil surface and in the clay dune are mainly composed of halite $(\mathrm{NaCl})$ and secondarily of gypsum $\left(\mathrm{CaSO}_{4} \cdot 2 \mathrm{H}_{2} \mathrm{O}\right)$. Mohamedou et al. (2001a) showed that their composition agrees with that of the water table. As water concentrates because of evaporation, the equilibrium with respect to these two minerals is reached, but 
the precipitation of thenardite $\left(\mathrm{Na}_{2} \mathrm{SO}_{4}\right)$ or mirabilite $\left(\mathrm{Na}_{2} \mathrm{SO}_{4} \cdot 10 \mathrm{H}_{2} \mathrm{O}\right)$ occurs very rarely and only in the most acid pans (Mohamedou et al., 2001a).

\subsection{Regional database}

The chemical results were sorted according to their chloride contents and are presented in concentration diagrams (Fig. 10). In these diagrams, the concentration factor (horizontal axis) is defined as $\mathrm{CF}=[\mathrm{Cl}] /[\mathrm{Cl}]_{0}$ where [] denotes the molarity and $[\mathrm{Cl}]_{0}$ refers to the

\section{T1}

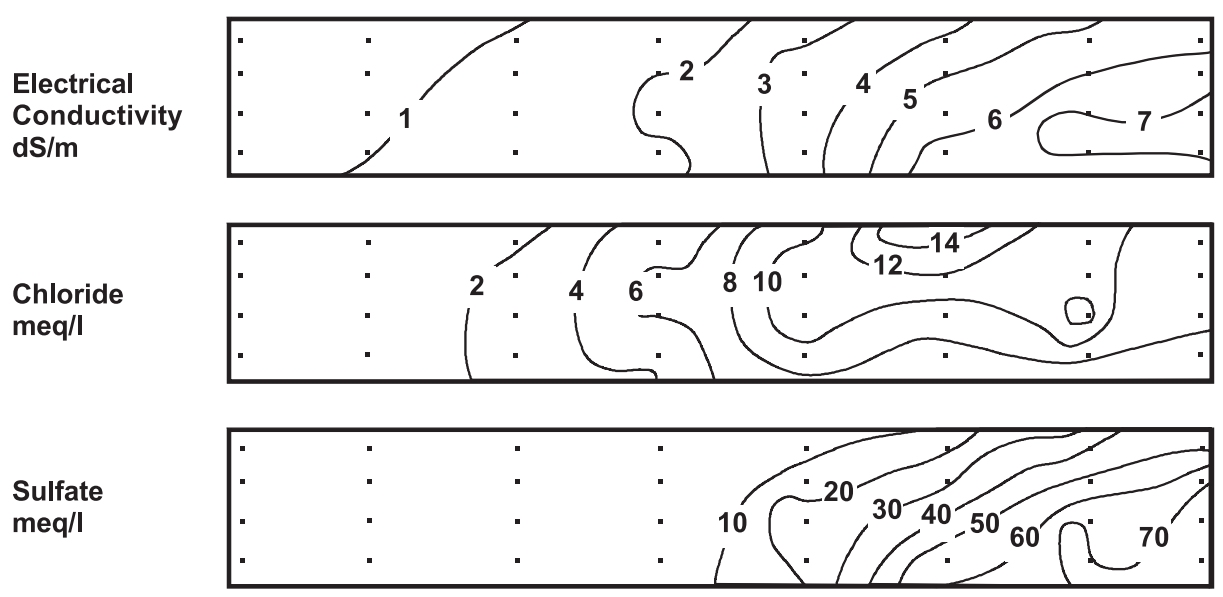

T2

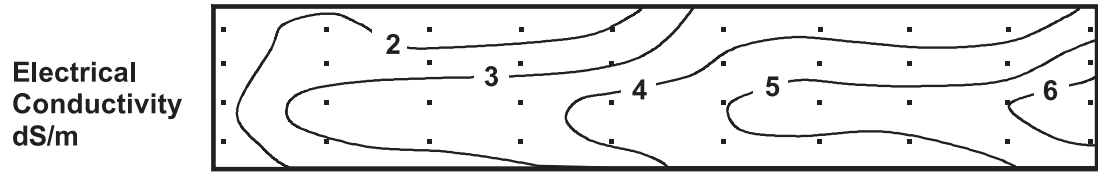

Chloride $\mathrm{meq} / \mathrm{l}$

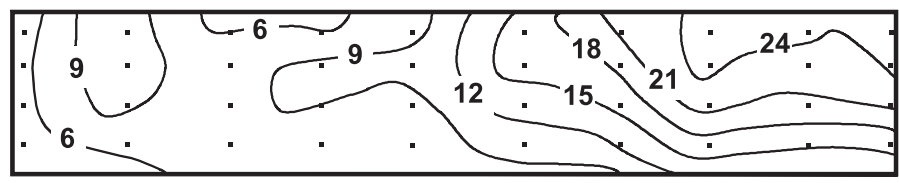

$1.4 \mathrm{~m} \mid \begin{aligned} & \text { Sulfate } \\ & \mathrm{meq} / \mathrm{l}\end{aligned}$

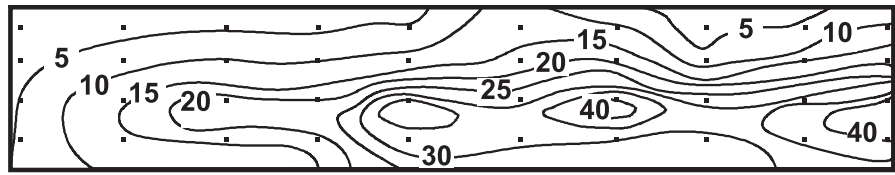

$5 \mathrm{~m}$

Fig. 8. Distribution of electrical conductivity, chloride and sulfate contents along vertical cross sections of transects T1-T4 in the N'Galenka area ( denotes sampling points). 


\section{Electrical Conductivity $\mathrm{dS} / \mathrm{m}$}

Chloride meq/l

Sulfate meq/l
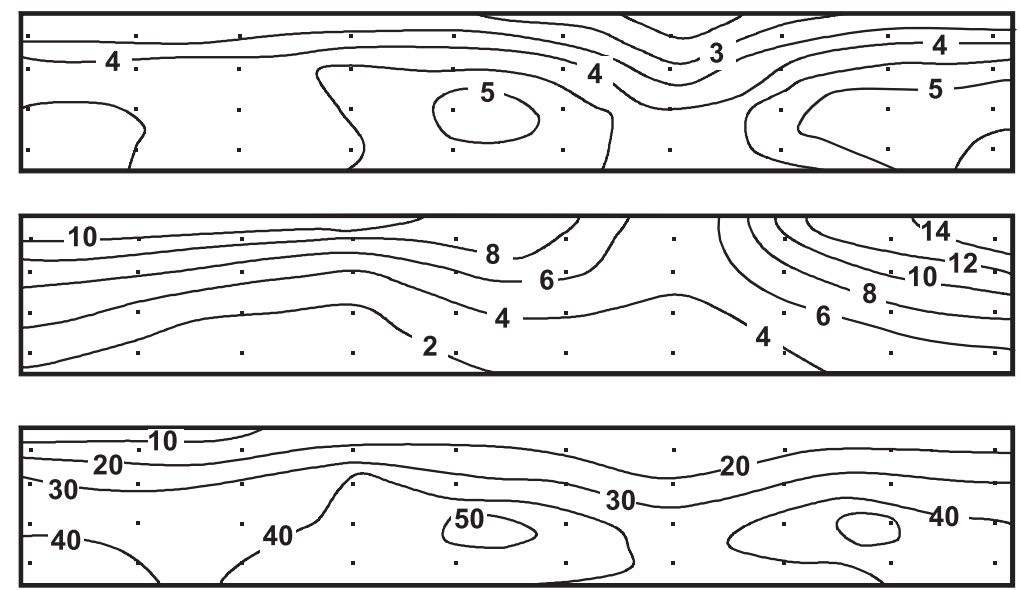

T4

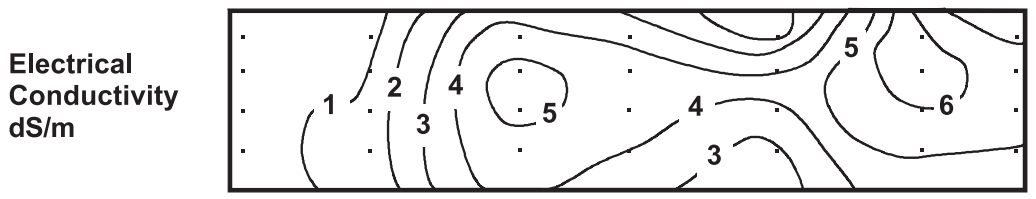

\section{Chloride} meq/l

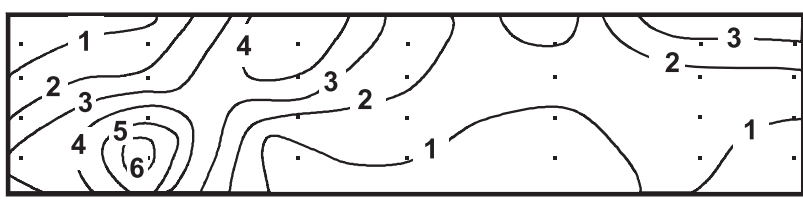

$1.4 \mathrm{~m} \mid \begin{aligned} & \text { Sulfate } \\ & \text { meq/l }\end{aligned}$

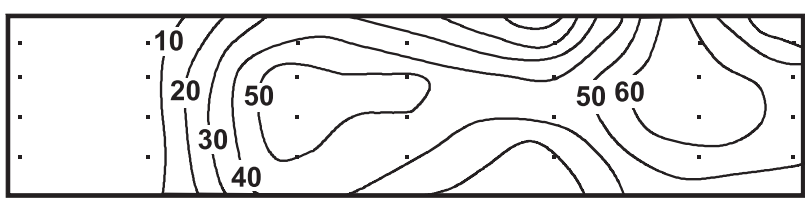

$5 \mathrm{~m}$

Fig. 8 (continued).

lowest $\mathrm{Cl}$ molarity measured. The concentration factor would be underestimated if halite $(\mathrm{NaCl})$ precipitates, but Mohamedou et al. (1999) showed that even for the greatest ionic strength measured $(4.43 \mathrm{M})$, the solution remains undersaturated with respect to halite. Therefore, precipitation of $\mathrm{NaCl}$ is not expected and chloride is a good indicator of the concentration factor. The vertical axis denotes the molarities of the major ions.

Some changes in the chemistry of the 1784 regional water samples occur along the valley. Upriver, the soil solutions are dominated by $\mathrm{HCO}_{3}^{-}$and $\mathrm{Ca}^{2+}$ ions, as is often true in continental Africa. The more saline samples downriver are dominated by $\mathrm{Cl}^{-}$and $\mathrm{Na}^{+}$, 

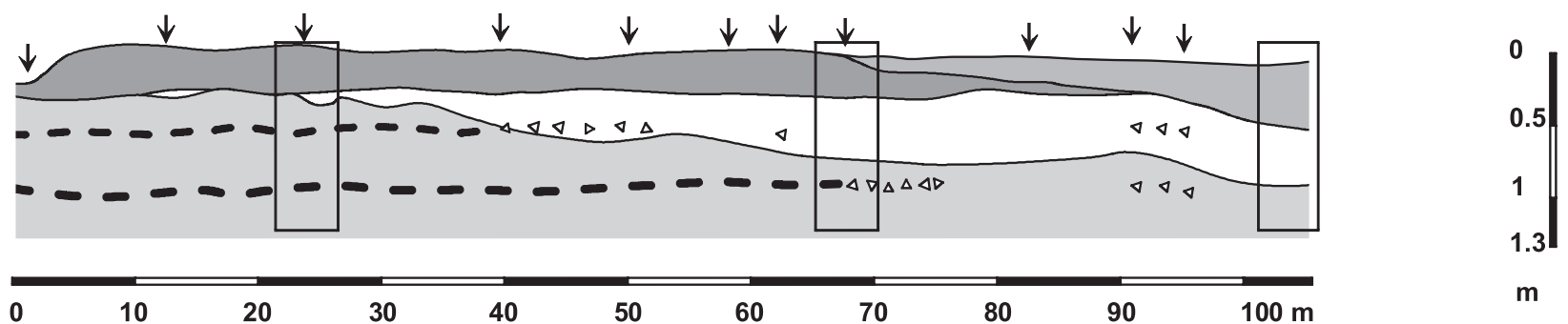

\section{Sequence 1}

w$$
\text { E }
$$

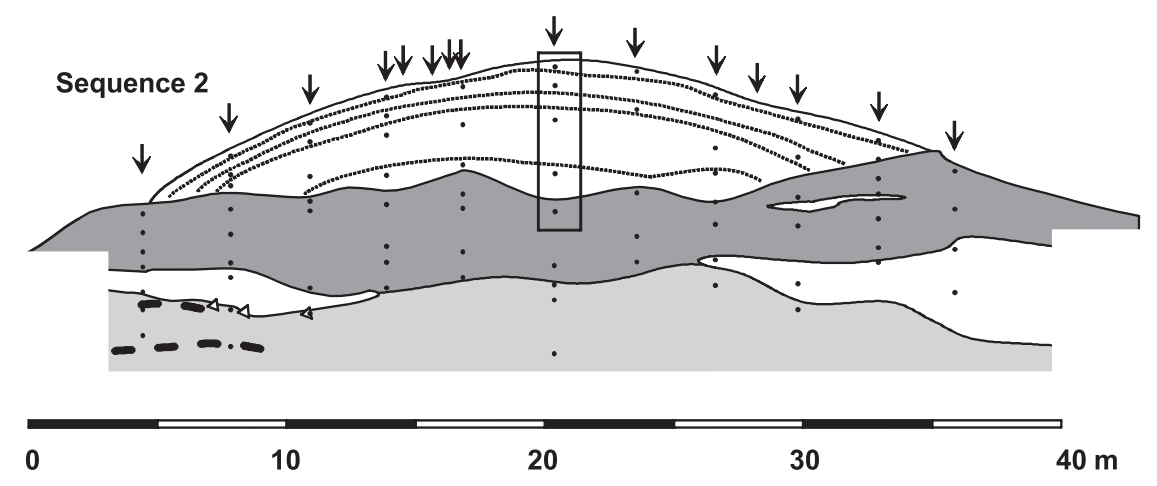

$\square$ Mud with pyrite and jarosite

$\square$ Superficial silty clay horizon

$\square$ Sandy horizon

$\square$ Superficial clay horizon

Stratified sandy clay loam material

- Shells and shell fragments

$\checkmark \triangleright$ Gypseous nodules

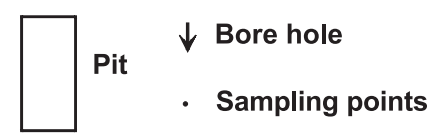

Fig. 9. Soil sequences 1 and 2 across the Khurumbam creek and clay dune in the Diawling park ( $\boldsymbol{\square}$ denotes sampling points on sequence 2). 

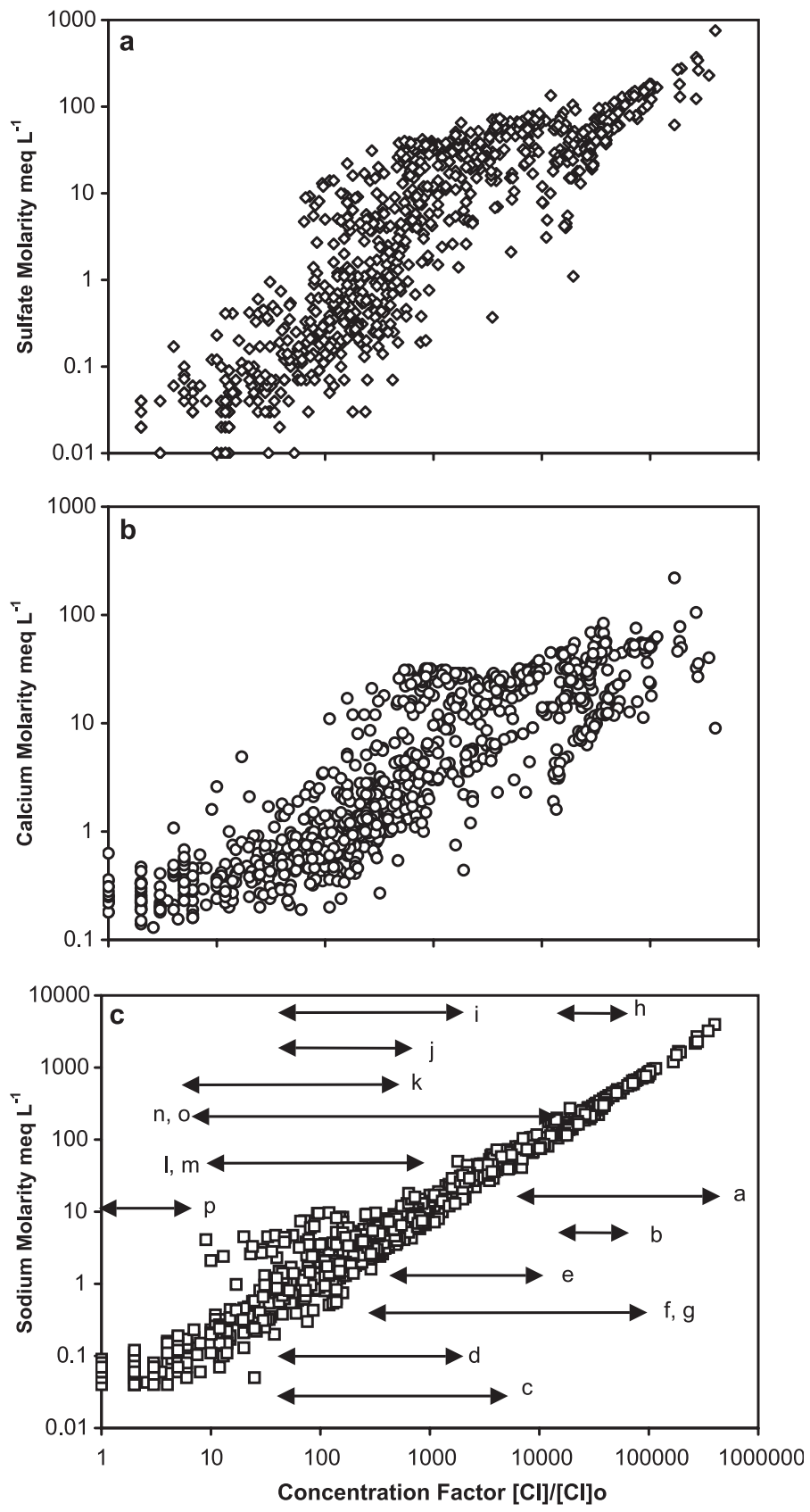

Fig. 10. Relationships between sulfate (a), calcium (b), sodium (c) and a concentration factor derived from chloride contents along the Senegal valley. Letters in (c) and the respective concentration ranges refer to the locations in Fig. 1. 
which agrees with their marine origin. The scatter plots of $\mathrm{Ca}^{2+}$ and $\mathrm{SO}_{4}^{2-}$ against $\mathrm{Cl}^{-}$ concentration factor exhibit an inflection at a concentration factor between 100 and 20000, where relatively high $\mathrm{Ca}^{2+}$ and $\mathrm{SO}_{4}^{2-}$ occur (Fig. 10a,b). There is a strong correlation between the $\mathrm{CF}$ for $\mathrm{Cl}^{-}$and $\mathrm{Na}^{+}\left(r^{2}=0.99\right.$, slope $\left.=1\right)$, although some data points depart from the straight line for CF values of 10-200 (Fig. 10c).

\section{Discussion}

\subsection{Salt accumulations in the delta}

Three types of salt accumulation occur at present in the Senegal delta. The first results from evaporation from the shallow water table, causing the precipitation principally of gypsum and halite in the topsoil; this will be referred to as evaporation salinity.

The second type is salt accumulation in clay dunes and will be called aeolian salinity. The clay dunes include further accumulations of gypsum and halite. The distribution of the thin sandy layers in the clay dune indicates that the dunes are fixed and grow symmetrically, which is contrary to the more common sand dunes (Bowler, 1973). The floor of the clay dune is protected from erosion and is therefore higher than the surrounding ground, which remains exposed to wind erosion.

The third type results from formation of gypsum from biological calcite. The soil in the creek bed (west part of sequence 1 in Fig. 9) has the typical morphology of acid sulfate soil (Dent, 1986). At the top of the profile and eastwards along the sequence, there are standard features arising from acidity following oxidation of pyrite, and also features of acidity controlled by soil alkalinity, including the progressive dissolution of the shells and eventual disappearance of the calcareous layers. The calcium released in the saline and sulfate rich environment precipitates as centimetric nodules of gypsum, indicating the former location of the shell layers. The quantity of gypsum involved depends on the amount of shells in the sediment and the quantity of acid released by oxidation of pyrite. The third type of salt accumulation is referred to as deep gypsum salinity.

\subsection{Sulfate-chloride relationships}

\subsubsection{Theory}

When marine water concentrates because of evaporation, changes in the chemical composition of the solution occur by precipitation of carbonates such as calcite and sulfates such as gypsum, and possibly thenardite or mirabilite. A correlation is expected between $\mathrm{SO}_{4}^{2-}$ and $\mathrm{Cl}^{-}$in the concentration diagram (pathway 1-2-3 in Fig. 11). From 1 to $2, \mathrm{SO}_{4}^{2-}$ increases in proportion to $\mathrm{Cl}^{-}$. Then from 2 to 3 , saturation with respect to gypsum is reached and $\mathrm{SO}_{4}^{2-}$ increases but less rapidly than $\mathrm{Cl}^{-}$because part of the $\mathrm{SO}_{4}^{2-}$ is taken from the solution to form gypsum. Precipitation of sodium sulfate occurs only at greater concentrations. Inversely, if dilution occurs, the pathway is reversed and the chemical composition follows the pathway $(3-2-1)$. From 3 to 2 , the $\mathrm{SO}_{4}^{2-}$ content decreases less than $\mathrm{Cl}^{-}$, because some of the gypsum previously precipitated in the soil redissolves. The soil solution is then at equilibrium with respect to gypsum. With further 


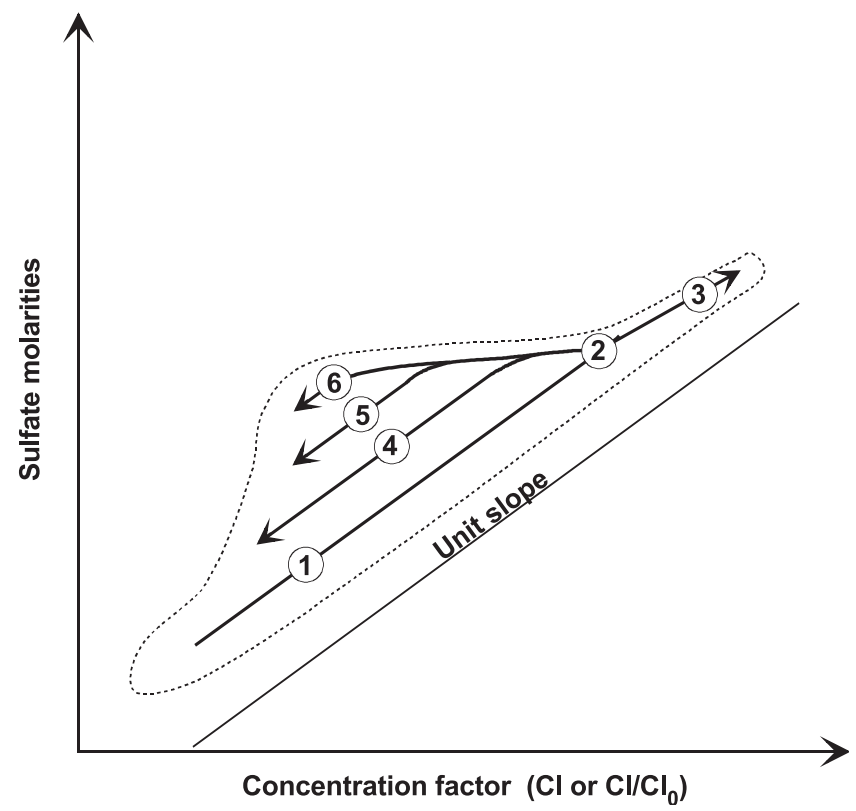

Fig. 11. Theoretical diagram of changes in sulfate molarities during concentration and dilution.

dilution $(2-1)$, the soil solution becomes undersaturated with respect to gypsum and concentrations of $\mathrm{SO}_{4}^{2-}$ and $\mathrm{Cl}^{-}$decrease proportionately. If dissolution of salts from aeolian salinity occurs, the relationship between $\mathrm{Cl}^{-}$and $\mathrm{SO}_{4}^{2-}$ will not be changed because aeolian salinity involves the same salts as evaporation salinity, i.e., gypsum and halite.

When deep gypsum occurs, the pathway followed by the soil solution during dilution in Fig. 11 coincides only partially with the theoretical evolution described above. From pathway 3 to $2, \mathrm{SO}_{4}^{2-}$ decreases less than $\mathrm{Cl}^{-}$, because some of the gypsum from the evaporation salinity dissolves. Because the solution remains at equilibrium with respect to the mineral, the deep gypsum remains undissolved. With further dilution, the soil solution becomes undersaturated and therefore aggressive with respect to gypsum, and deep gypsum begins to dissolve until saturation is reached again. The solution becomes enriched with $\mathrm{Ca}^{2+}$ and $\mathrm{SO}_{4}^{2-}$ ions and evolves along pathways 4, 5 or 6 (Fig. 11), which depends on the quantity of gypsum in the soil. As long as gypsum is not exhausted, the $\mathrm{CF}$ for $\mathrm{Cl}^{-}$decreases but the $\mathrm{Ca}^{2+}$ and $\mathrm{SO}_{4}^{2-}$ contents are maintained in the soil solution. After complete elimination of the deep gypsum, $\mathrm{Ca}^{2+}$ and $\mathrm{SO}_{4}^{2-}$ decrease in proportion to the dilution effect, i.e., parallel to the slope of the lines drawn in Fig. 11.

\subsubsection{In the samples}

The above theoretical model can explain the relationships between $\mathrm{Cl}^{-}$and $\mathrm{SO}_{4}^{2-}$ in the delta and in the middle valley. In the delta, the variability in the salinity is due to concentration/dilution of the soil solution, whose chemical composition possibly includes gypsum and halite from aeolian salinity dissolved during rainfall or during Senegal 
flooding. Dissolution of the deep gypsum is noticed only for some samples taken immediately beneath the floor of the clay dune in the gypseous layers (asterisks on Fig. 7), where the solution gets enriched in $\mathrm{SO}_{4}^{2-}$ and $\mathrm{Ca}^{2+}$. In the middle valley, the chemical composition of samples from group 1 can be related to concentration/dilution of the same soil solution, in which dissolution of salt from aeolian salinity could have occurred. The samples from group 2 with higher relative proportion of $\mathrm{SO}_{4}^{2-}$ and $\mathrm{Ca}^{2+}$ cannot result only from evaporation of the same soil solution as in group 1. Nevertheless, the chemical composition in group 2 agrees with the influence of another source of salt such as deep gypsum dissolution.

\subsection{Distribution of saline areas in the middle valley}

The distribution of the saline strips in the middle valley is similar to that of the clay dunes in the delta. Clay dunes and saline areas are usually located along the creeks on their southern leeward bank. The saline areas have roughly similar dimensions to the clay dunes + creek beds (about 100-200 m wide and several kilometers long), suggesting again that saline areas are related to aeolian salt accumulation in clay dunes. The strong associations between saline strips and former creek channels shown in Fig. 5 suggests that the site studied in the N'Galenka is representative of the region. Similar patterns have already been described at other sites, namely M'Boyo, Donaye and Nianga (Barbiéro, 1999) around Podor. We attribute the southern substrip to the former clay dune associated with the creek and the northern substrip to the former creek bed salinized by runoff containing salt from the southern bank.

\subsection{Temporal model for salt evolution along the valley}

These observations suggest a new four-stage model explaining the distribution of salinity and the variable composition of the soil solution (Fig. 12). Stage 1 was the period of accumulation of pyrite by sulphur-fixing bacteria in a waterlogged environment supplied with seawater sulfate under a tidal influence. In Stage 2, the drainage resulting from the marine regression brought oxygen into the previously waterlogged soils, and the pyrite was oxidized to form sulfuric acid. At this stage, only the creeks were still occupied by mangrove vegetation. The shell beds dissolved and became gypseous horizons. The shallow water table evaporated and the rapid crystallization of gypsum and halite in the topsoil caused the development of a soft powdery structure. The aggregates of the powdery structure were vulnerable to wind deflation, and therefore accumulated behind wind-breaking obstacles as clay dunes, especially on the southern banks of the creeks. The first two stages are currently observed in the Senegal delta.

In Stage 3, the water table was at a lower level and no longer subject to evaporation. The rains of the wet season and the seasonal overflows of the Senegal River resulted in partial desalinization of the soils. Evaporation salinity was eliminated from areas around the clay dunes by the percolating water, but the clay dunes themselves remained saline for a longer time because of the greater quantity of salt in them. By dissolving some superficial gypsum, percolating water became saturated with respect to this mineral and therefore non-aggressive on reaching the deep gypsum. The deep gypsum began to 

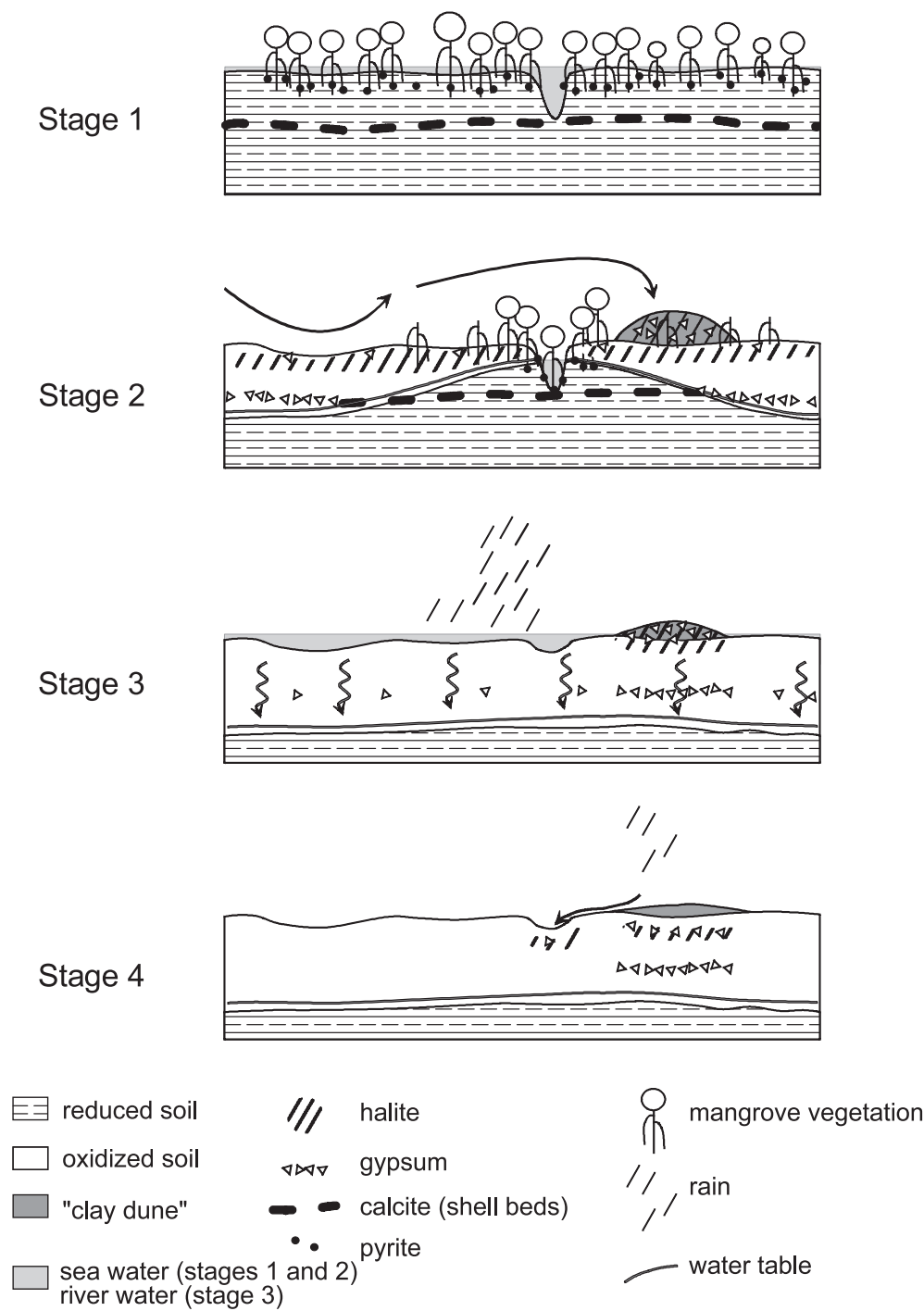

Fig. 12. The four-stage model for the origin of saline areas in the Senegal valley.

dissolve only after almost complete elimination of the superficial gypsum (Stage 4). Surface runoff could then cause secondary salinization in depressions located near former clay dunes, i.e., the creek bed. Where secondary salinization occurred, the chemical composition of the salinity in the creek bed would have been similar to that of the superficial part of the soil. Conversely, the composition of the topsoil salinity differed from the deep gypseous horizons, because chloride content was greater in the superficial layer.

The four-stage model agrees with the morphological and geochemical features observed in the Senegal valley. Many iron pipes, which are traces of the former mangrove 
vegetation, are observed in the soil as far inland as Boghé, located $380 \mathrm{~km}$ upstream from the coast (Michel, 1973), and attest to the previous influence of mangrove vegetation on the soil chemistry. The aeolian redistribution of salt of marine origin into clay dunes on higher ground adjacent to creek beds explains the occurrence of saline substrips on the leeward sides of previous creek channels in the middle valley (Barbiéro et al., 2001). Both types of saline substrip have dimensions roughly similar to those of the clay dunes and creek beds. The secondary salinization of the creek bed may occur by runoff of salts from the clay dune above, as in transect T4. The model also explains the distribution of salinity chemistry in the transects, which is dominated by chloride and sulfate in the topsoil (aeolian salinity) and just sulfate at $80 \mathrm{~cm}$ depth (deep gypsum salinity).

The quantity of deep gypsum salinity should be influenced by variation in the initial quantities and distributions of the shells and pyrite originally present in the sediment. Isolated centimetric nodules of gypsum are common, but compact slabs of gypsum have been reported in the delta (Loyer, 1989, p. 59). In Table 1, the average composition of the transects differs from that of the regional database because desalinization is occurring in the middle valley as suggested in Stage 4. At this stage, the deep gypsum is dissolving and influences the soil solution chemistry, increasing the $\mathrm{Ca}^{2+}$ and $\mathrm{SO}_{4}^{2-}$. In contrast, in many places downriver, the soil solution is still very saline and deep gypsum dissolves very little or not at all.

The data provided by previous reports suggest the regional applicability of this scenario in the Senegal valley (Fig. 10). The straight line correlation between $\mathrm{Cl}^{-}$and $\mathrm{Na}^{+}$(Fig. 10c) from a broad range of soil solutions can be interpreted by concentration/ dilution processes along the valley. However, the organisation of the scatter plots of $\mathrm{Ca}^{2+}$ and $\mathrm{SO}_{4}^{2-}$ (Fig. 10a and b) cannot be explained only by concentration/dilution, but with the model including the dissolution of deep gypsum salinity. Our conclusions agree with those of Samba Diene (1998), who attributed the accumulation of deep gypsum to a process independent of the present soil solution chemistry at a site in the lower middle valley.

On Fig 10c, the samples that do not fit the strong correlation between sodium and chloride molarities for concentration factors between 10 and 300 suggest that small quantities of sodium sulfate (thenardite or mirabilite) are possibly incorporated into the deep gypsum, and dissolve with it when dilution occurs. Such precipitation could occur under very acidic conditions, as shown by Mohamedou et al. (2001a). These samples were collected in a former clay dune at M'Boyo, located about $20 \mathrm{~km}$ upstream from Podor. The unusual chemistry of the saline soil solution may be specific to this location or may predict a change in the chemical composition of the saline areas upriver from Podor. We do not have pertinent data to explain the deviation of these samples from the correlation more definitely.

\section{Conclusions}

Previous researches in the middle valley of the Senegal River have attributed the formation of saline areas to marine salts deposited in the sediment during the most recent marine transgression. However, this fails to explain the present distribution and features of 
the saline areas. Based on their morphology and geochemistry, the presence of saline areas results from the presence of former clay dunes, but their chemical characteristics are explained by a four-stage salt accumulation involving: (1) concentration in the groundwater because of evaporation, (2) aeolian deflation and clay dune formation, (3) transformation of shell banks into gypseous layers under acidic conditions generated by oxidation of pyrite and (4) local salinization by runoff. The four-stage accumulation of salts has developed under restricted environmental conditions, which are similar to those observed today in the delta, where their evolution continues. The regional applicability of this model is supported by a database collected along the valley.

Our results suggest that the soils in the valley form a chronosequence, in which the most recent occur in the delta and the earlier, more developed, soils occur upriver near the limit of the last marine transgression. We have already used the chronosequence concept to describe the pedological processes involved in the development of soil profiles in the valley (Barbiero et al., in press). It may also be useful in studying the evolution of other soil features, such as the natural control of the acidity of the mangrove swamps and the influence of water alkalinity on possible soil degradation resulting from irrigation.

The salinization process is currently occurring only in the delta and no longer in the middle valley, where only the salt present at about $60 \mathrm{~cm}$ depth can be remobilised by field irrigation. As currently observed in many irrigation schemes, this can cause problems in agriculture. Because the presence of saline areas cannot be easily detected from the soil surface, rapid mapping of saline soil distribution using electromagnetic induction methods and aerial photographs to identify former geomorphological features, is an essential prerequisite for the establishment of new irrigation schemes in this region.

\section{Acknowledgements}

This work was partially realised in the framework of the PSI-CORAF (Regional Coordination of the Irrigated Systems Pole of the Conference of Agronomic Research Directors in Africa). We thank Samba Seck and Alfred Savadogo for help in collecting data, and Dr. Vasanthi Dass for editorial advice.

\section{References}

Barbiéro, L., 1999. Comment prévoir la répartition des sels dans la vallée du fleuve Sénégal? In: Legoupil, J.C., Dancette, C., Godon, P., Ndiaye, K.M. (Eds.), Pour un Développement Durable de L'agriculture Irriguée Dans la Zone Soudano-Sahélienne. Synthèse des Résultats du Pôle Régional de Recherche sur les Systèmes Irrigués. PSI-Coraf Publication, Dakar, Senegal, pp. 404-419.

Barbiéro, L., Laperrousaz, C., 1999. Cartographie de la salinité dans la vallée du Sénégal. Succès d'une démarche ascendante. Pangea 31/32, 5-7.

Barbiéro, L., Mohamedou, A.O., Caruba, R., 1998a. Influence de la maturation des sols de mangrove sur la déflation éolienne et la formation de dunes argileuses dans le delta du fleuve Sénégal. Comptes Rendus de l'Académie des Sciences Paris 327, 115-120. 
Barbiéro, L., Hammecker, C., Boivin, P., 1998b. Aeolian origin of some saline soil stripes in the Senegal middle valley. Morphological and geochemical considerations. Proceedings of the 16e ISSS World Congress, August 20-26, 1998, Montpellier.

Barbiéro, L., Cunnac, S., Mané, L., Laperrousaz, C., Hammecker, C., Maeght, J.L., 2001. Salt distribution in the Senegal middle valley. Analysis of a saline structure on planned irrigation schemes from N'Galenka Creek. Agricultural Water Management 46, 201-213.

Barbiéro, L., Mohamedou, A.O., Roger, L., Furian, S., Aventurier, A., Rémy, J.C., Marlet, S., in press. The origin of Vertisols and their relationship to acid sulfate soils in the Senegal valley. Catena.

Bertrand, R., Keita, B., N’Diaye, M.K., Veldkamp, W.J., 1997. La dégradation des sols irrigués en Afrique de l'Ouest. In: Miézan, K.M., Wopereis, M.C.S., Dingkuhn, M., Deckers, J., Randolph, T.F. (Eds.), Irrigated Rice in the Sahel: Prospects for Sustainable Development. WARDA/ADRAO, Dakar, Senegal, pp. $51-68$.

Boivin, P., 1997. Soil degradation in irrigation schemes in the Senegal middle valley. In: Miézan, K.M., Wopereis, M.C.S., Dingkuhn, M., Deckers, J., Randolph, T.F. (Eds.), Irrigated Rice in the Sahel: Prospects for Sustainable Development. WARDA/ADRAO, Dakar, Senegal, pp. 37-49.

Bowler, J.M., 1973. Clay dunes: their occurrence, formation and environmental significance. Earth-Science Reviews 9, 315-338.

Braudeau, E., 1978. Etude pédologique de la cuvette de Nianga (Secteur A)—Région du fleuve Sénégal. Research Report, Dakar-Hann ORSTOM Centre, Senegal.

Braudeau, E., 1981. Etude pédologique du périmètre de Balky (ex. colonat de Richard Toll), région du fleuve Sénégal. Research Report, Dakar-Hann ORSTOM Centre, Senegal.

Brito, J., 1982. Etude pédologique du casier de Kobilo, département de Matham, région du fleuve Sénégal. Research Report, Dakar-Hann ORSTOM Centre, Senegal.

Ceuppens, J., Wopereis, M.C.S., 1999. Impact of non drained irrigated rice cropping on soil salinization in the Senegal river delta. Geoderma 92, 125-140.

Cunnac, S., 1996. Etude de la variabilité spatiale de la salinité des sols des futurs périmètres irrigués du Marigot N'Galenka. End of cours Memoire ESA Purpan, Toulouse, France.

Deckers, J., Dondeyne, S., Vandekerckhoven, L., Raes, D., 1997. Major soils and their formation in the West African Sahel. In: Miézan, K.M., Wopereis, M.C.S., Dingkuhn, M., Deckers, J., Randolph, T.F. (Eds.), Irrigated Rice in the Sahel: Prospects for Sustainable Development. WARDA/ADRAO, Dakar, Senegal, pp. $23-35$.

Dent, D., 1986. Acid Sulphate Soils: A Baseline for Research and Development. International Institute for Land Reclamation and Improvement (ILRI) Publication 39, Wageningen, The Netherlands.

De Poitevin, F., 1993. Etude d'impact des techniques culturales sur les aménagements hydro-agricoles dans la région de Podor, Sénégal. End of cours Memoire ESA Purpan, Toulouse, France.

Diba, M., 1995. Analyse comparée de deux méthodes d'évaluation de la répartition spatiale de la salinité des sols: pâte saturée et conductivimétrie électromagnétique. End of cours Memoire Institut des Sciences de la Terre, University of Dakar, Senegal.

Faure, H., Fontes, J.C., Hebrard, L., Monteillet, J., Pirazzoli, P.A., 1980. Geoidal changes and shore-level tilt along Holocene estuaries: Senegal river area, West Africa. Science 210, 421-423.

FAO-SEDAGRI, 1973. Etude hydro-agricole du bassin du fleuve Sénégal. Etude pédologique SEDAGRI, Paris, France.

FAO/ISRIC/ISSS, 1998. World Reference Base for Soil Resources. Rome, Italy.

Gascuel-Odoux, C., Boivin, P., 1994. Variability of variograms and spatial estimates due to soil sampling: a case study. Geoderma 62, $165-182$.

Geotronics, P., 1980. Couverture aérienne, mission Teledyne Geotronics (USA). Photographies Infra-rouge fausses couleurs 1/50000éme.

Gran, G., 1952. Determination of the equivalence point in potentiometric titrations: part II. Analyst 77, 661 -671.

Hammecker, C., Maeght, J.L., 2002. Suivi et évaluation de la qualité des eaux et de l'impact environnemental des aménagements du secteur N'Gallenka. 2nd Report, Institut de Recherche pour le Développement, Dakar, Senegal.

Laval, F., 1996. Rapport d'activités. Travaux d'expérimentation ORSTOM-FED dans la moyenne vallée du Fleuve Sénégal. Région de Podor. Research Report, Dakar-Hann ORSTOM Centre, Senegal. 
Le Brusq, J.Y., 1980. Etude pédologique des cuvettes de la vallée du Lampsar (Région du fleuve Sénégal). Research Report, Dakar-Hann ORSTOM Centre, Senegal.

Le Brusq, J.Y., Loyer, J.Y., Mougenot, B., Carn, M., 1987. Nouvelles paragenèses à sulfates d'aluminium, de fer, et de magnésium, et leur distribution dans les sols sulfatés acides du Sénégal. Science du Sol 25, $173-184$.

Loyer, J.Y., 1989. Les sols salés de la basse vallée du fleuve Sénégal Caractérisation, distribution et évolution sous cultures. ORSTOM Publication, Collection Etudes et Thèses, Paris, France.

Loyer, J.Y., Diallo, M.A., 1979. Notes sur les sols et les nappes de la cuvette de N'Delle-N'Diaye. Research Report, Dakar-Hann ORSTOM Centre, Senegal.

Loyer, J.Y., M’Timet, A., 1979. Etude pédologique de la cuvette de N’Dieyrba (Région du fleuve Sénégal). Research Report, Dakar-Hann ORSTOM Centre, Senegal.

Maymard, J., 1952. Les sols du pseudo-delta du Sénégal. Mission d'aménagement du Sénégal, Bulletin no. 5 , Centre ORSTOM de Dakar Hann, Senegal.

Maymard, J., Combeau, A., 1960. The residual effect of submersion on soil structure (demonstrated by applying S. Henin's index of structural instability). African Soils/Sols Africains 5, 123-148.

McNeill, J.D., 1992. Rapid accurate mapping of soil salinity by electromagnetic ground conductivity meters. Advances in Measurements of Soil Physical Properties: Bringing Theory into Practice. Special PublicationSoil Science Society America, vol. 30, pp. 209-230.

Meyer, L., 1997. Etude du transport des sels au cours des écoulements et de l'évolution des propriétés physiques du sol au contact de différentes solutions salines. Mémoire Ecole Polytechnique Fédérale de Lausane, Lausanne, Switzerland.

Michel, P., 1973. Les bassins des fleuves Sénégal et Gambie. Etude géomorphologique. Mémoires ORSTOM, Paris, France.

Mohamedou, A.O., 1998. Contribution à l'étude de l'environnement du Parc National du Diawling (Mauritanie). Eaux-Sols-Végétation. PhD thesis, Univ. Nice-Sophia Antipolis, France.

Mohamedou, A. O., 2000. Evolution pédogénétique des sols de mangrove de la vallée du fleuve Sénégal et phénomènes associés. Rapport Post-Doctoral, Univ. Nouakchott, Mauritania.

Mohamedou, A.O., Aventurier, A., Barbiéro, L., Caruba, R., Valles, V., 1999. Geochemistry of clay dunes and associated pan in the Senegal delta (Mauritania). Arid Soil Research and Rehabilitation 13, 265-280.

Mohamedou, A.O., Barbiéro, L., Furian, S., Ciornei, G., Caruba, R., 2001a. Origine et répartition des sels dans la vallée du fleuve Sénégal (Sénégal-Mauritanie). Science et Changements Planétaires Sécheresse 12, $251-257$.

Mohamedou, A.O., Barbiéro, L., Furian, S., Caruba, R., 2001b. L'érosion du sol en fonction du système pédologique dans le Parc National du Diawling, Mauritanie. Science et Changements Planétaires Sécheresse $12,183-186$.

Mougenot, B., 1982. Etude pédologique de la cuvette de N'Tiagar (Partie Nord), delta du fleuve Sénégal. Research report, Dakar-Hann ORSTOM Centre, Senegal.

OMVS (Organisation pour la Mise en Valeur du fleuve Sénégal), 1975. The objectives and the main outlines of the integrated development strategy of the Senegal river basin. Organisation pour la Mise en Valeur du Fleuve Sénégal, Dakar, Senegal.

Price, W.A., 1963. Physicochemical and environmental factors in clay dune genesis. Journal of Sedimentary Petrology 33, 766-778.

Samba Diene, R., 1998. Riziculture et dégradation des sols en vallée du fleuve Sénégal: Analyse comparée des fonctionnements hydro-salins des sols du delta et de la moyenne vallée en simple et double riziculture. $\mathrm{PhD}$ thesis, Univ. Dakar, Senegal.

Seiny Boukar, L., 1983. Etude pédologique de la cuvette de N’Der, lac de Guiers (Région du fleuve Sénégal). Research Report, Dakar-Hann ORSTOM Centre, Senegal.

Szabolcs, I., 1992. Salinization of soil and water and its relation to desertification. UNEP Desertification Control Bulletin 21, 32-37.

Thomas, D.S.G., 1988. The nature and depositional setting of arid and semi arid Kalahari sediments, southern Africa. Journal of Arid Environments 14, 17-26.

Thomas, D.S.G., Nash, P.A., Shaw, P.A., Van der Post, C., 1993. Present day lunette sediment cycling at witpan in the arid southwestern Kalahari desert. Catena 20, 515-527. 
Verheye, W.H., 1995. Impact of climate and soil conditions on conception and implementation of irrigation schemes in the Senegal River basin. Agricultural Water Management 28, $73-94$.

Vieillefon, J., 1967. Sur l'existence de bourrelets éoliens ou "lunettes" dans les mangroves de Casamance. In: Comité Panafricain de Préhistoire et de l'Etude du Quaternaire, Dakar, Senegal (Ed.), Préhistoire et étude du Quaternaire-Congrès Panafricain. Chambery, France, pp. 436-441.

Zanolin, A., Tchani, J., Barbiéro, L., Boivin, P., Descloitres, M., 1997. Apport de la méthode électrique pour la reconnaissance hydrogéologique et l'étude des variations superficielles en zone sédimentaire subsaharienne. In: BRGM, INRA, ORSTOM, UPMC (Eds.), Géophysique des sols et des formations Superficielles, Bondy, France, pp. $173-178$. 